
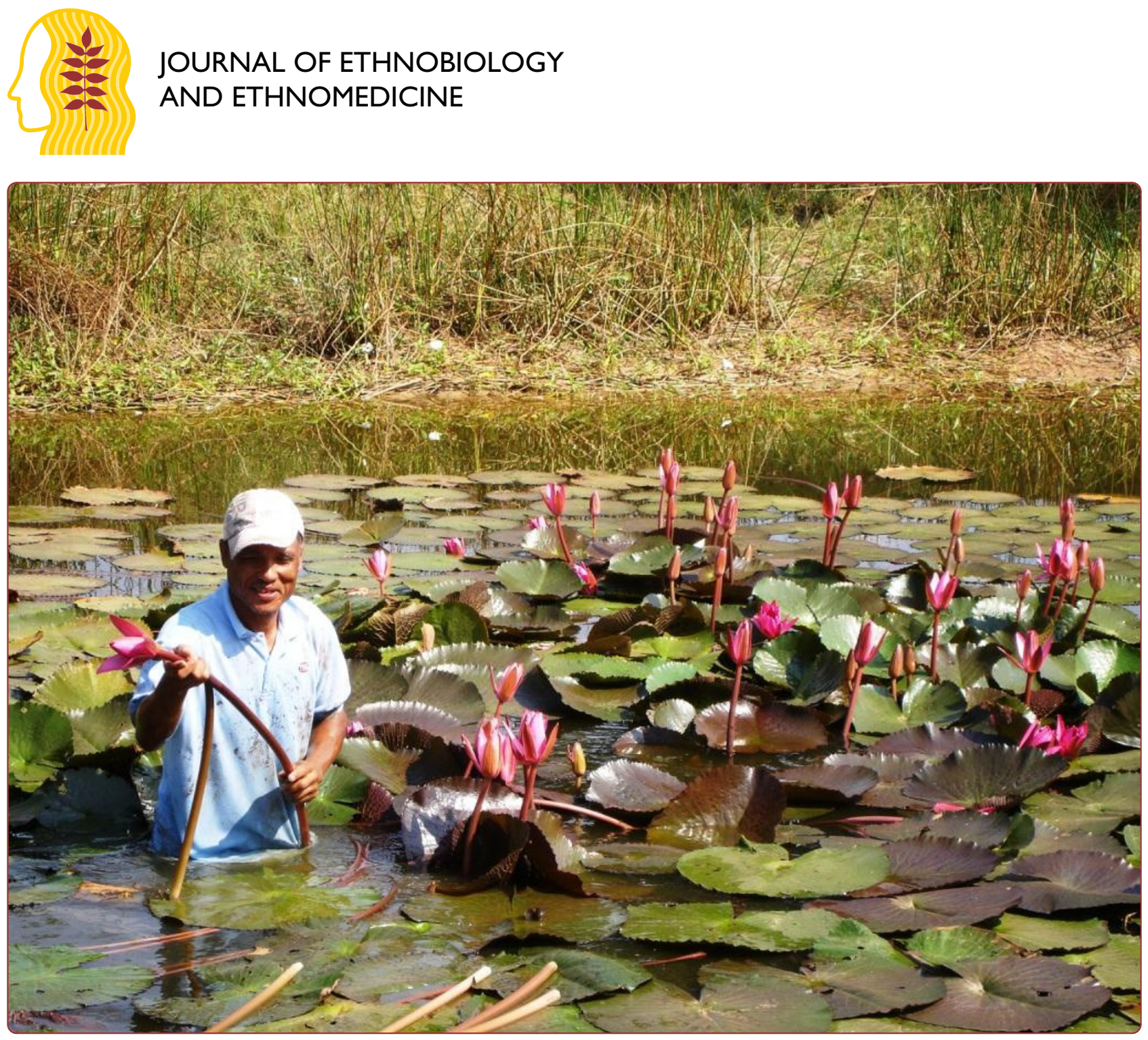

\title{
Ethnobotanical investigation of 'wild' food plants used by rice farmers in Kalasin, Northeast Thailand
}

Cruz-Garcia and Price 


\title{
Ethnobotanical investigation of 'wild' food plants used by rice farmers in Kalasin, Northeast Thailand
}

Gisella S Cruz-Garcia ${ }^{1,2^{*}+}$ and Lisa L Price $2,3+$

\begin{abstract}
Background: Wild food plants are a critical component in the subsistence system of rice farmers in Northeast Thailand. One of the important characteristics of wild plant foods among farming households is that the main collection locations are increasingly from anthropogenic ecosystems such as agricultural areas rather than pristine ecosystems. This paper provides selected results from a study of wild food conducted in several villages in Northeast Thailand. A complete botanical inventory of wild food plants from these communities and surrounding areas is provided including their diversity of growth forms, the different anthropogenic locations were these species grow and the multiplicity of uses they have.

Methods: Data was collected using focus groups and key informant interviews with women locally recognized as knowledgeable about contemporarily gathered plants. Plant species were identified by local taxonomists.

Results: A total of 87 wild food plants, belonging to 47 families were reported, mainly trees, herbs (terrestrial and aquatic) and climbers. Rice fields constitute the most important growth location where $70 \%$ of the plants are found, followed by secondary woody areas and home gardens. The majority of species (80\%) can be found in multiple growth locations, which is partly explained by villagers moving selected species from one place to another and engaging in different degrees of management. Wild food plants have multiple edible parts varying from reproductive structures to vegetative organs. More than two thirds of species are reported as having diverse additional uses and more than half of them are also regarded as medicine.
\end{abstract}

Conclusions: This study shows the remarkable importance of anthropogenic areas in providing wild food plants. This is reflected in the great diversity of species found, contributing to the food and nutritional security of rice farmers in Northeast Thailand.

Keywords: Wild food plant, ethnobotany, rice ecosystem, edible part, use, growth location, growth form, gathering, Thailand, Southeast Asia

\section{Background}

The collection and consumption of 'wild' plant foods from agricultural and non-agricultural ecosystems has been documented in multiple cultural contexts, illustrating their use and importance among farming households throughout the world [1-3]. The evidence to date suggests that gathering by farmers occurs in various

\footnotetext{
* Correspondence: gisella.cruz@wur.nl

† Contributed equally

${ }^{1}$ Centre for Crop Systems Analysis, Department of Plant Sciences,

Wageningen University, Wageningen, The Netherlands

Full list of author information is available at the end of the article
}

environments, ranging from intensively farmed areas, to more subsistence oriented horticultural systems, and finally in more pristine areas such as forests. This is certainly the case of rice farmers in Asia [4]. For example, Ogle et al. [5,6] found that in the Mekong Delta of Vietnam $90 \%$ of women eat wild vegetables, uncovering a total of 94 species. Kosaka [7], in his research on flora from the paddy rice fields in Savannakhet, Laos, recorded 11 edible species from a total of 19 herbaceous useful plants, and 25 food trees out of 86 useful species. The documentation of 'wild' food plant gathering and consumption in mainland Southeast Asia is still

\section{() Biomed Central}


growing, however the literature is scattered across numerous disciplines [8].

The research on which this paper is based was conducted in Kalasin Province, Northeast Thailand. Studies conducted in this region provide documentation that 'wild' food plants are a critical component in the subsistence system of farmers [9-14]. This food resource is extremely important to the rural population comprised of rice farmers, given that the Northeast region is regarded as both Thailand's largest and poorest part of the country. This paper adds to this literature by providing the most comprehensive botanical inventory of these foods to date. Two botanical characteristics are described in this article: growth form and life cycle. Moreover, we present the growth location of the plants. Regarding cultural characteristics, this paper also identifies multiple uses of wild food plants.

Wild food plants in this article refer to non-domesticated plants. These plants exist on a continuum of people and plants interactions in regard to their degree of management. In this way, wild food plants include those from 'truly' wild to wild protected, cultivated and semidomesticated plants that may be promoted, protected or tolerated in some way locally. Wild food plants can be cultivated, but not all cultivated plants are domesticated. For most species the transition from cultivation to domestication never happens. Human plant management does not necessarily move toward greater intensity and ultimately plant domestication. While some plants are moving towards domestication, other plants that used to be highly managed in the past could be only slightly tolerated and protected under contemporary circumstances [1]. While we include in our definition 'introduced' and 'naturalized' plants, locally domesticated plants are excluded. We use the term 'local' because, since the nature of this study is ethnobotanical, we based our research on these plants that are classified as 'wild' by local people. This is why some food plants that are regarded as 'wild' in Kalasin, might be treated as domesticates in other areas.

\section{The research site}

The research for this paper was conducted in four villages in Kalasin Province, Northeast Thailand. The villages are fairly typical for the region. Kalasin is located at $152 \mathrm{~m}$ above sea level (asl) in the Korat Plateau, which geographically defines the Northeast region of the country. This Plateau, forming a shallow depression between $100 \mathrm{~m}$ and $200 \mathrm{~m}$ asl, is generally quite flat with scattered swamps and ponds (some seasonal) and low hills that rise to around $300 \mathrm{~m}$ asl [15].

Soils in this region are mostly heavily leached fine sandy loams, with poor drainage and high salinity. Furthermore they are usually low in phosphate, nitrogen and organic matter [15]. Declining soil fertility is prevalent in the region [16]. Nevertheless, the soils in lowland paddy fields are better than in the uplands because they receive nutrient in-flows eroded from the higher areas [17]. The natural vegetation of this region is dry monsoon forest, primarily composed by dry dipterocarp forest $[15,18]$, with Dipterocarpus tuberculatus Roxb., D. obtusifolius Teijsm. ex Miq., Shorea obtusa Wall., S. siamensis Miq., Xylia xylocarpa (Roxb.) Taub., Irvingia malayana Oliv. ex A.M. Bennett, Cratoxylon formosum (Jack) Dyer. and Careya arborea Roxb. as dominant species [19].

Deforestation has been occurring at a high rate since the early 1950s with the extension of agricultural land due to commercialization of agriculture, as well as population growth. In this way, the forest and wooded areas have decreased from $90 \%$ in the 1930 s to less than $14 \%$ in 2004 . The rate of deforestation was likely augmented significantly during the economic crisis at the end of the 1990s $[16,20]$. At the same time, soil degradation in the agricultural areas has been increasing and consequently yields have declined [17].

The Northeast covers 170, $000 \mathrm{~km}^{2}$ [17] and has more land dedicated to agriculture than the rest of the country (9.25 million hectares). Around 94\% of the region's population live in rural areas [21], with the region possessing the highest number of farms in the Nation $(2,273,000)$ [22]. Indeed, in Kalasin province $85.1 \%$ of the population depend on agriculture [23]. The main crop is glutinous rice (also called sticky rice), which is important as the dietary staple and for income generation. Rice production corresponds to $70 \%$ of the arable land of the Northeast, but average rice yields are the lowest in the country (1.8 $\mathrm{Mg} \mathrm{ha}^{-1}$ ) [16]. Within the traditional rain-fed paddy agricultural system, which is primarily transplanted rice, crops can be damaged by delayed rains when transplanting seedlings, or by droughts and floods $[15,16]$. The annual monsoon provides $90 \%$ of the annual rainfall of the Northeast, averaging over $200 \mathrm{~mm}$ from May through October, which is essential for the cultivation of glutinous rice. From November to April, rainfall averages only about $20 \mathrm{~mm}$ per month in Kalasin [24].

\section{The research population}

The Northeast is referred to as Isaan and is also known for its distinct cultural characteristics. The people who inhabit the region, commonly referred to as Isaan people, are ethnically of Lao origin, constituting one of the largest minority populations in the country. Most Northeasterners speak a dialect of Lao mixed with some influences from Thai also known as Isaan. Isaan is written using the Thai script. Thai is learned formally in school and villagers are literate in Thai, except for the very elderly. 
Kalasin Province has a population of about one million inhabitants and a density of 132.3 inhabitants $/ \mathrm{km}^{2}$. Households on average have four family members in the rural areas, and $23.6 \%$ of them are female headed. Theravada Buddhism is the main religion in this province (99.5\% of the population), as in the rest of the country. The population has attained on average 6.5 years of education. Regarding their work status, $51.7 \%$ are unpaid family workers and $35.8 \%$ are engaged in selfemployment, usually in agriculture [23]. There is a high rate of seasonal or full-time migration to major cities mainly as wage labourers who aim to send remittances to their families that stay in the rural areas [19]. Offfarm employment accounts for two thirds of the total income of families in Northeast Thailand [21].

There is customary inheritance of land through women and a pattern of matrilocal residence. This system facilitates women having a thorough knowledge of their social and physical environment [8].

\section{General overview of wild food plants in Northeast Thailand}

An important yet not widely available study at the national level established that wild food plants play an essential role in the diet in all the rural areas of Thailand [25]. This is clearly reflected in the fact that more than 500 different edible natural products have been documented as being sold in the markets around the country [26].

Gathering mainly occurs in anthropogenic ecosystems, such as agricultural lands (including paddy fields), woody areas, (home) gardens, house areas and swamps $[12,14,27]$. Agricultural lands and home gardens are traditionally owned by women [28-30]. In Northeast Thailand, women are the main gatherers, selectors, transplanters and propagators of wild food plants [27-33].

In this region farmers have as their staple glutinous rice accompanied by a variety of wild foods derived from wild, semi-domesticated and domesticated plants, as well as frogs, paddy crabs, insects and fish. During the rainy season wild food can constitute as much as half of the total food consumed in the villages. Wild food plants are mainly consumed as fresh fruits or vegetables eaten raw or steamed, and in local "curries" or soups [34,35].

In fieldwork conducted in Northeast Thailand in 1990, Price documented 77 species gathered by farmers in a village in Kalasin Province [14,36]. Somnasang, Rathakette and Rathanapanya [34] listed 42 wild vegetables and 7 wild fruits in a paper published in the 1980s. Ten years later, Somnasang, Moreno-Black and Chusil [33] recorded 66 wild food plants consumed in Northeast Thailand. Furthermore, Sapjareun, Kumkrang and
Deewised [37] published a book, in Thai, entitled "Local vegetables in Isaan" presenting a general description of a number of plants by species, their propagation, ecological importance and uses, as well as the local recipes.

\section{The botanical-dietary paradox}

One of the important characteristics of wild plant foods among farming households is that the main collection locations are increasingly from the anthropogenic ecosystems such as agricultural areas rather than pristine ecosystems [14]. Ogle and Grivetti [38] in their study in Swaziland found that the most intensively cultivated area among their research sites exhibited the highest level of loss of edible species, but, at the same time, the most consumption of wild food plants. They termed this phenomenon the "botanical-dietary paradox" and proposed that this occurs when people start to rely on eating the weeds of agriculture once a decline in forests occurs. Ultimately, the species that are considered local vegetables change. Price and Ogle [8] further explain that time constraints are a major factor in the commencement of the botanical-dietary paradox in that as forests decrease and become more remote from the village, gathering from the forests becomes increasingly too time consuming, so farmers shift to gathering in areas closer to home and shift to eating many of the weeds of agriculture and other food plants in the agricultural system. This shift in food resources is evident on Mainland Southeast Asia.

Saowakontha et al. [39] conducted a study on edible forest products in two villages, Ban Moh and Ban Nong Khong, Phu Wiang district, in Northeast Thailand, presenting a list of 34 wild food plants. They found that the degree of dependency on this resource was related to the distance from the village to the forest, thus, the longer the distance to the forest, the higher the dependency on other areas for food gathering. Likewise, Kosaka et al. [40,41] compared two rice farming villages from Savannakhet Province, Laos, obtaining the same results. Whereas Bak village, located in the uplands with an extensive forest area, showed to be more dependent on forest diversity, farmers from Nakou village, situated in the lowlands with a small area of remnant forest, identified more useful plants from the rice fields than the forest, compensating for the lack of resources by maintaining the tree diversity within the paddy rice fields. Studies conducted specifically on non-timber forest products provide surprising results. For example, in a study conducted in the Lao P.D.R., the researchers discovered that farmers used multiple land types and that $60 \%$ of the non-timber forest products were not from the forest at all but were collected from fields (paddy, dry grass areas, and fallow), streams and ponds [42]. The same happened when Shibahara conducted research on 
hunting and gathering in public forests of Roi Et, Northeast Thailand. Although research was focused on forest areas, a major finding was that farmers relied mainly on wild foods from rice fields rather than forests. Shibahara also emphasized that most gathering activities occurred on private land instead of public land [43]. The role of private land in food gathering entitlements among Northeast Thai villagers has been documented by Price [14].

Given the alarming rate of decrease in forest and wooded areas in Thailand [44] it is becoming increasingly important to also study the wild food plants from anthropogenic areas, as several studies have shown that farmers are becoming more dependent on these places for ensuring their household dietary diversity and food security $[8,12,14,45,46]$.

Somnasang, Rathakette and Rathanapanya [34] found that paddies are a principal place for gathering wild vegetables and fruits in Northeast Thailand. Likewise, Price [14] estimated that farmers gather more from the fields than from any other place. Indeed, rice fields are not only important in terms of rice production but are biologically diverse [47] and multi-resource agro-ecosystems [9]. According to the International Rice Research Institute [4], paddies possess over 100 useful associated plant species being sources of food, medicine, fibre, construction material, fuel and animal feed.

\section{Anthropogenic ecosystems}

Rice fields on the plains of Northeast Thailand and Laos are characterized by having trees in the paddy fields, given their importance for local culture [40] and their socio-economic and ecological functions [48]. Trees are either planted or remnants from a previous forest, which went through different stages of transformation until becoming a rice field during the historical and ongoing process of agricultural expansion $[9,17,18]$. The transition point was named "rice production forest" by Takaya and Tomosugi [49]. Vityakon et al. [17] recognize different transitional historical stages of land use change, which they describe at the regional, community, landscape and field level in their article "From forests to farm fields: changes in land use in undulating terrain of Northeast Thailand at different scales during the past century". Prachaiyo [18] also explains this process in his publication entitled "Farmers and forests: a changing phase in Northeast Thailand".

There are a number of studies on the diversity of trees in paddy fields in Northeast Thailand. Grandstaff, Rathakette, and Thomas [9] recorded 54 species of trees and shrubs, 32 of them used as food and/or medicine, growing in the rice fields. Watanabe et al. [50] recorded 16 useful tree species growing in paddy fields in the region. Additionally, Vityakon [48,51-53] conducted research on the importance of trees for soil fertility in rice fields. She identified 25 species (14 of them used as food and/or medicine) surviving from previous forests, indicating, if applicable, their uses as food and/or medicine [51]. Later on, Prachaiyo [18] described 28 useful tree species growing in the paddies mainly for timber, latex, food, medicine, oil or fodder. Subsequently, Tipraqsa [19] emphasized the importance of trees in rice fields in Northeast Thailand, documenting 52 trees found in the diverse farming systems in the rice landscape. Finally, trees in rice fields have also been systematically documented in Laos by Kosaka et al. [7], and also discussed in the symposium "Tree-Rice Ecosystem in the Paddy Fields of Laos" organized by a JapaneseThai project on the same topic, where the utilization of some tree species as food was noted [54].

Plant diversity in rice fields not only consists of trees, but also aquatic and terrestrial herbs, climbers and shrubs. However, several herbs, climbers and shrubs are classified as weeds or invasive species by agronomists. Yet, a number of weeds are used as vegetables or medicines in Thailand. Maneechote [55] documents 59 edible weeds indicating their parts eaten and the habitat where they grow, which corresponds to about 30\% of the 150 plant species classified as weeds in the country. Vongsaroj and Nuntasomsaran [56] conducted a literature review on weed utilization in Thailand reporting 33 weeds used as food, 16 as medicine and 12 as animal feed; some of them were also listed later on in Vongsaroj's [57]. Kosaka et al. [41] identified 11 edible species, 5 medicinal species and 2 plants used as animal feed, mostly weeds from the paddy fields in Savannakhet, Laos.

Prachaiyo also listed some herbs used as vegetable or medicinal plants growing in the rice fields of Northeast Thailand [18]. Although weeds have been shown to have diverse uses around the world [58], they are continuously overlooked in their role as sources of food and medicine [55]. Minor attention is paid to weed utilization in Thailand given that most agricultural research is focused on minimizing their population [56].

\section{This study}

Despite the recognition of the important role that wild food plants play for farmers' livelihoods in Northeast Thailand, information is rather scattered throughout different publications, which are mainly in the Thai language. There is no single article presenting not only an exhaustive list of species but also their local name and, botanical and cultural characteristics. This is certainly necessary as a baseline for future research in this area.

The objectives of this paper are to provide selected results from an ethnobotanical study of wild food plants conducted in Northeast Thailand. A complete botanical 
inventory of wild food plants used by the study villages and their surrounding areas is provided including their diversity of growth forms, the different anthropogenic locations were these species grow and the multiplicity of uses they have. The research presented in this paper contributes to understanding the importance of different anthropogenic ecosystems where wild food plants grow and provides insights on the multiplicity of uses of these plants.

\section{Methods}

\section{Taxonomic identification and plant naming}

Fieldwork was conducted from 2006 to 2010, taking as a baseline the results obtained in research carried out by one of the authors in two adjacent villages located in Kalasin Province, where she identified 77 species classified as 'wild' food plants during focus group elicitations conducted with local farmers [14]. This list was built upon and increased using focus groups and key informant interviews as complementary methods in the same villages. A final list of 87 species of locally classified 'wild' food plants was constructed and local names of plants in the local Thai-Lao vernacular were recorded in the Thai script. Species were botanically identified by taxonomists from the Department of Biology of Chang Mai University and Walai Rukhavej Botanical Research Institute of Mahasarakham University. Herbarium specimens of most of the identified species are on repository in one or more locations in Thailand, including the Bangkok Herbarium of the Department of Agriculture (BK) in Bangkok, Herbarium of Walai Rukhavej Botanical Research Institute (WRBG) in Mahasarakham, and the Herbarium of Khon Kaen University (KKU) in Khon Kaen. Botanical naming of family, genus and species follows "Flora of Thailand" [59].

The villagers use the term geht eng, which means "birth itself" for wild food plants. However they do distinguish between "birth itself" as a type of plant versus just the verb "to birth by itself" (without human intervention, such as sowing or transplanting). Some "birth itself" species can also be transplanted or propagated, as some domesticates such as tomatoes can "birth themselves" (growing from consumption debris). Domesticates that "birth themselves" are not considered wild food plants ("birth itself" type of plant). Plant types are further identified by prefixes. The most common prefixes used for naming food plants refer to their edible part, such as bak and maak that mean fruit (บัก, หมาก), yod meaning shoots (ยอด), bai (which is a more unusual prefix) referring to leaf (ใบ), and dok that means flower (ดอก). A very common prefix for naming wild food plants is phak which means vegetable (ผัก) [14]. Phak includes shoots, leaves, stems and sometimes whole aerial parts eaten as vegetable. In this way, if a plant has more than one edible part, it will likely have more than one name differing in the prefix used. For example, Garcinia cowa has two local names Phak moong (ผักโมง) and Bak moong (บักโมง) given that it is eaten as both vegetable and fruit. A total of 131 plant names were documented for the 87 plants, giving an average of 1.5 names per plant. Plant names were carefully recorded in the local Isaan dialect (capturing both pronunciation and local tone) using the Thai script. Plant names were also transliterated into English. Finally, English names were obtained from Germplasm Resources Information Network (GRIN) [60], Multilingual Multiscript Plant Name Database (MMPND) [61] and Plant Resources of Southeast Asia (PROSEA) [62].

\section{Ethnobotanical data collection}

Growth form and life cycle were determined for each species through field observation and complemented with literature [63]. Growth location and cultural characteristics of the plants, such as edible parts and multiple uses, were assessed through focus groups and supplemented with key informant interviews conducted not only in the research villages but also in two additional nearby villages. The use of different methods permitted, to a certain degree, triangulation and greater depth. These activities were carried out with the aid of local translators who speak the Thai-Lao vernacular of the Lao language (Isaan) as it is spoken in the research location and are knowledgeable about the research topic. Finally, a relational data base of wild food plants was built using Microsoft ${ }^{\circledR}$ Access.

Focus groups are particularly useful when the everyday use of language and culture of particular groups is of interest, and when one wants to explore the degree of consensus on a given topic [64]. The focus group method has previously been successfully applied to the collection of plant species level information with farmers in Northeast Thailand [14]. Each focus group consisted of six to nine members, following Bernard's recommendations on the number of participants [65]. Focus group participants were generally middle-age women or slightly older (34 to 66 years old), named by the villagers themselves as knowledgeable about contemporarily gathered plants [65,66]. A total of 12 sessions were carried out sometimes with different participants, each session lasted two to three hours and was tape recorded. All of who participated in the study did so freely and with consent.

\section{Results and discussion}

\section{Botanical characteristics of wild food plants}

A total of 87 wild food plants, belonging to 47 families, were mentioned by farmers through key informant interviews and focus group discussions in 2006, building up on a previous list of plants documented by Price in 1990. Out of this total, 76 plants were botanically 
identified to the species level recognizing a total of 75 different species (two plants correspond to different sub-species of the same species), 9 were identified to genus level and for two botanical identification was not possible (Table 1). About $13 \%$ of the plants were from the Leguminoseae family (6 species belonged to Mimosoideae and 5 to Caesalpinioideae). Other important families were Annonaceae, Myrtaceae, Poaceae, Pontederiaceae, Sapindaceae, Zingiberaceae, with 3 species each.

Two categories of life cycles were considered: annual and perennial. Some $79 \%$ of the wild food plants were perennial and $21 \%$ annual. For analysing growth form, seven categories were considered: aquatic herb, terrestrial herb, climber, shrub, tree, bamboo and rattan. Figure 1 shows that almost half of the wild food plants were trees (44\%). Other important growth forms were terrestrial herb (18\%), aquatic herb (15\%) and climber (13\%). Shrubs only presented five plants, followed by bamboo with three plants and rattan with only one plant. Climber and terrestrial herbs were both annual and perennial, while aquatic herbs were only annual plants. Trees, shrubs, bamboos and rattans were all perennial plants.

\section{Growth location of wild food plants}

From an ecological perspective, local farmers provided two major kinds of answers when they were asked where a plant grows. Firstly, (a) they gave general names of what ecologists regard as anthropogenic ecosystems, such as rice field or home garden; and secondly (b) they provided names of specific sub-systems of an anthropogenic ecosystem, such as field margin, tree row or water pond, which all are part of the rice ecosystem. In order to facilitate the analysis, the answers were grouped into six major growth locations: rice field, secondary woody area, home garden, upland field, swamp and roadside, including plants that grow in any of the sub-systems. The analysis of the ethnoecological classification of growth locations (local emic categorization) was not an objective of this paper. The six major growth locations of wild food plants are the following:

1. Rice field, containing a diverse range of aquatic, semi-terrestrial and terrestrial niches, is where most wild food plants, roughly $70 \%$, can be found. Only six plants out of 61 are exclusively found in the rice fields (mainly terrestrial herbs regarded as weeds), whereas the rest can also be found in other places, mostly home gardens (64\%), secondary woody areas (45\%), upland fields (40\%) and swamps (20\%). In rice fields it is possible to find aquatic herbs such as Nymphaea pubescens and Neptunia oleracea; terrestrial herbs such as Limnophila aromatica and Amaranthus viridis; trees as Borassus flabellifer and Leucaena leucocephala; and climbers like Coccinia grandis.

2. Fifty-five percent of the plants occur in secondary woody areas, which are mainly public areas located outside the farms, near upland fields. Only eight out of 48 plants were noted as growing exclusively in woody areas, whereas the rest grow also in other locations, mainly rice fields (68\%) and/or home gardens (65\%), some of which having been transplanted by the villagers. Most of the wild food plants growing in the woody areas are trees (65\%), such as Azadirachta indica (also growing in home gardens and rice fields) and Canarium subulatum (found only in woody areas). A culturally important terrestrial herb only gathered in woody areas is Curcuma singularis, which is gathered in the rainy season.

3. Fifty-two percent of the plants occur in home gardens. There were no plants exclusive to home gardens, all plants could be found in other locations, mainly rice fields (78\%), woody areas (58\%) and upland fields (49\%). Many species growing in home gardens are transplanted from other areas and subject to different degrees of management, such as Tamarindus indica. Species in home gardens are mostly trees (e.g. Phyllanthus acidus) and climbers (e.g. Tiliacora triandra and Momordica charantia), followed by a few terrestrial herbs (e.g. Centella asiatica).

4. Upland fields, mainly consisting of fields with cash crops of cassava and sugar cane, contain $37 \%$ of the wild food plant species. No plants were exclusive to the upland fields. Wild food plant species that occur in upland fields also grow in other locations, mainly woody areas (84\%), rice fields (69\%) and home gardens (69\%). Most species are trees such as Syzygium gratum and Careya arborea.

5. Swamps contained $17 \%$ of the plants. Three out of 15 plants were exclusive to swamps, but these are rarely found. The rest of the plant species also occur in rice fields, with the exception of Neptunia javanica which is a terrestrial herb found in home gardens and roadsides. Regarding their growth form, $75 \%$ are aquatic herbs such as Hydrolea zeylanica, while $25 \%$ are terrestrial herbs such as Oenanthe javanica.

6. Thirteen percent of the plants grow on roadsides. No plants were exclusive to roadsides. All plants found at roadsides also grow in home gardens. Nine roadside plant species also occur in the rice fields, seven in the upland plantations and six in the woody areas. Most of the wild food roadside plant species were trees such as Pithecellobium dulce and Cassia siamea. There are a few climbers such as Passiflora foetida.

Wild food plants are widely distributed in the anthropogenic landscape. The results show that $80 \%$ of the wild food plants can be found in multiple growth 
Table 1 List of wild food plants

\begin{tabular}{|c|c|c|c|}
\hline Scientific name & $\begin{array}{l}\text { English transliteration of local } \\
\text { (Isaan) name }\end{array}$ & $\begin{array}{l}\text { Local (Isaan) } \\
\text { name }\end{array}$ & English name \\
\hline \multicolumn{4}{|l|}{ Aizoaceae } \\
\hline Glinus oppositifolius (L.) Aug.DC. & Phak kaen khom & ผักแก่นขม & \\
\hline \multicolumn{4}{|l|}{ Amaranthaceae } \\
\hline Amaranthus viridis $\mathrm{L}$. & Phak hom & ผักหม & green amaranth, pigweed, slender amaranth \\
\hline \multicolumn{4}{|l|}{ Anacardiaceae } \\
\hline Mangifera caloneura Kurz & Bak muang paa & บักม่วงป่า & \\
\hline Spondias pinnata Kurz & Bak kawek & บักกอก & $\begin{array}{l}\text { common hog plum, Indian mombin, } \\
\text { Andaman mombin }\end{array}$ \\
\hline \multicolumn{4}{|l|}{ Annonaceae } \\
\hline Polyalthia debilis Finet \& Gagnep. & Bak lok kok & บักลกคก & \\
\hline Polyalthia evecta Finet \& Gagnep. & Bak tong leeng & บักต้องแล่ง & \\
\hline Uvaria pierrei Finet \& Gagnep. & Bak pii puwen & บักพิผ่วน & \\
\hline \multicolumn{4}{|l|}{ Araceae } \\
\hline Amorphophallus sp. & Phak e-loke & ผักอีลอก & \\
\hline \multicolumn{4}{|l|}{ Araliaceae } \\
\hline \multirow[t]{2}{*}{ Irvingia malayana Oliver } & Bak bok & บักบก & barking deer's mango \\
\hline & Maak bok & หมากบา & \\
\hline \multicolumn{4}{|l|}{ Arecaceae } \\
\hline \multirow[t]{2}{*}{ Borassus flabellifer L. } & Bak taan & บักตาล & palmyra palm, tala palm, wine palm \\
\hline & Yod taan & ยอดตาล & \\
\hline \multirow[t]{2}{*}{ Calamus sp. } & Bak waai & บักหวาย & \\
\hline & Waai & หวาย & \\
\hline \multicolumn{4}{|l|}{ Asclepiadaceae } \\
\hline \multirow[t]{3}{*}{ Telosma minor Craib } & Phak kik & ผักขิก & \\
\hline & Dok kik & ดอกขิก & \\
\hline & Bak kik & บักขิก & \\
\hline \multicolumn{4}{|l|}{ Basellaceae } \\
\hline Basella rubra L. & Phak pang & ผักปัง & $\begin{array}{l}\text { Ceylon-spinach, Malabar-nightshade, vine- } \\
\text { spinach }\end{array}$ \\
\hline \multicolumn{4}{|l|}{ Bignoniaceae } \\
\hline Dolichandrone serrulata Seem. & Kee paa & แคป่า & \\
\hline \multirow[t]{4}{*}{ Oroxylum indicum Vent. } & Phak lin faa & ผักลิ้นฟ้า & midnight horror, oroxylum \\
\hline & Bak lin faa & บักลิ้นฟ้า & \\
\hline & Yod lin faa & ยอดลิ้นฟ้า & \\
\hline & Bai lin faa & ใบลิ้นฟ้า & \\
\hline \multicolumn{4}{|l|}{ Burseraceae } \\
\hline Canarium subulatum Guillaumin & Bak luwam & บักเหลื่อม & \\
\hline \multicolumn{4}{|l|}{ Campanulaceae } \\
\hline Lobelia begonifolia Wall. & Phak luem phua & ผักลืมผัว & \\
\hline Lobelia sp. & Phak som & ผักสัม & \\
\hline \multicolumn{4}{|l|}{ Clusiaceae } \\
\hline $\begin{array}{l}\text { Cratoxylum formosum (Jack) Benth. \& Hook.f. } \\
\text { ex Dyer }\end{array}$ & Phak tew & ผักดิ้ว & \\
\hline \multirow[t]{2}{*}{ Garcinia cowa Roxb. } & Phak moong & ผักโมง & cowa \\
\hline & Bak moong & บักโมง & \\
\hline \multicolumn{4}{|l|}{ Compositae } \\
\hline Blumea balsamifera DC. & Phak naad & ผักหนาด & \\
\hline Emilia sonchifolia (L.) DC. & Phak lin pii & ผักลิ์นปี & emilia, sow thistle \\
\hline
\end{tabular}


Table 1 List of wild food plants (Continued)

\begin{tabular}{|c|c|c|c|}
\hline \multicolumn{4}{|l|}{ Convolvulaceae } \\
\hline Cuscuta chinensis Lam. & Phak mai tong & ผักไหมทอง & Chinese dodder \\
\hline Ipomoea aquatica Forssk. & Phak bung & ผักบัง & $\begin{array}{l}\text { Chinese water-spinach, swamp morning- } \\
\text { glory }\end{array}$ \\
\hline \multicolumn{4}{|l|}{ Cucurbitaceae } \\
\hline \multirow[t]{3}{*}{ Coccinia grandis (L.) Voigt } & Phak tam nin & ผักตำนิน & ivy gourd, little gourd \\
\hline & Bak tam nin & บักตำนิน & \\
\hline & Tam nin & ตำนิน & \\
\hline \multirow[t]{2}{*}{ Momordica charantia L. } & Phak sai & ผักไส & balsam-apple, bitter gourd, bitter melon \\
\hline & Bak phak sai & บักผักไส่ & \\
\hline \multicolumn{4}{|l|}{ Ebenaceae } \\
\hline Diospyros rhodocalyx Kurz & Maak koo & หมากโก & \\
\hline \multicolumn{4}{|l|}{ Euphorbiaceae } \\
\hline \multirow[t]{2}{*}{ Phyllanthus acidus (L.) Skeels } & Bak yom & บักยม & $\begin{array}{l}\text { gooseberry-tree, Indian-gooseberry, star- } \\
\text { gooseberry }\end{array}$ \\
\hline & Yod bak yom & ยอดบักยม & \\
\hline \multicolumn{4}{|l|}{ Fagaceae } \\
\hline Castanopsis sp. & Bak kaaw & บักก่อ & \\
\hline \multicolumn{4}{|l|}{ Gnetaceae } \\
\hline Gnetum sp. & Bak muway & บักหม่วย & \\
\hline \multicolumn{4}{|l|}{ Hydrocharitaceae } \\
\hline Ottelia alismoides (L.) Pers. & Phak hob hep & ผักโหบเหบ & duck-lettuce, water-plantain ottelia \\
\hline \multicolumn{4}{|l|}{ Hydrophyllaceae } \\
\hline Hydrolea zeylanica (L.) J.Vahl & Phak ka-liang & ผักกะเหลียง & Ceylon hydrolea \\
\hline \multicolumn{4}{|l|}{ Lauraceae } \\
\hline Cassytha filiformis $\mathrm{L}$. & Phak mai & ผักไหม & dodder-laurel \\
\hline \multicolumn{4}{|l|}{ Lecythidaceae } \\
\hline \multirow[t]{2}{*}{ Barringtonia acutangula (L.) Gaertn. } & Phak kadon naam & ผักกะโดนน้ำ & Indian-oak \\
\hline & Kadon naam & กะโดนน้ำ & \\
\hline \multirow[t]{2}{*}{ Careya arborea Roxb. } & Phak kadon kok & ผักกะโดนโคก & \\
\hline & Kadon kok & กะโดนโคก & \\
\hline \multicolumn{4}{|l|}{ Leguminosae } \\
\hline Adenanthera pavonina L. & Phak lam & ผักล่า & coralwood, red sandalwood-tree \\
\hline \multirow[t]{2}{*}{ Cajanus cajan (L.) Millsp. } & Bak tua heea & บักถั้วแฮ & pigeon-pea, red gram \\
\hline & Tua heea & ถั่วแฮ & \\
\hline \multirow[t]{2}{*}{ Cassia siamea Lam. } & Phak khee lek & ผักขี้เหล็ก & kassodtree, Thai cassia, Siamese senna \\
\hline & Khee lek & ขี้เหล็ก & \\
\hline Dialium cochinchinense Pierre & Bak keng & บักเค็ง & velvet-tamarind \\
\hline \multirow[t]{4}{*}{ Leucaena leucocephala (Lam.) de Wit } & Phak kased & ผักกะเสด & leadtree, white popinac, leucaena \\
\hline & Bak kased & บักกะเสด & \\
\hline & Yod phak kased & ยอดผักกะเสด & \\
\hline & Kased & กะเสด & \\
\hline Neptunia javanica Miq. & Phak kased kok & ผักกะเสดโคก & \\
\hline Neptunia oleracea Lour. & Phak kased naam & ผักกะเสดน้ำ & water-mimosa \\
\hline \multirow[t]{2}{*}{ Pithecellobium dulce (Roxb.) Benth. } & Bak kaam lian & บักขามเลียน & blackbead, Manila tamarind, sweet-inga \\
\hline & Kaam lian & ขามเลียน & \\
\hline Senna sophera (L.) Roxb. & Phak let ket & ผักเล็ดเค็ด & Kasondi senna \\
\hline Sindora siamensis Teijsm. ex Miq. & Bak tee & บักแต้ & \\
\hline
\end{tabular}


Table 1 List of wild food plants (Continued)

\begin{tabular}{|c|c|c|c|}
\hline \multirow[t]{4}{*}{ Tamarindus indica $\mathrm{L}$. } & Bak kaam & บักขาม & tamarind \\
\hline & Bak kaam som & บักขามสัม & \\
\hline & Maak kaam & หมากชาม & \\
\hline & Yod kaam & ยอดขาม & \\
\hline \multirow{2}{*}{$\begin{array}{l}\text { Xylia xylocarpa Taub. var kerrii (Craib \& } \\
\text { Hutch) I.C. Nielsen }\end{array}$} & Bak deeng & บักแดง & \\
\hline & Maak deeng & หมากแคง & \\
\hline \multicolumn{4}{|l|}{ Liliaceae } \\
\hline \multirow[t]{2}{*}{ Asparagus racemosus Willd. } & Phak shi shang & ผักชิช้าง & Indian asparagus \\
\hline & Shi shang & ซีช้าง & \\
\hline \multicolumn{4}{|l|}{ Limnocharitaceae } \\
\hline \multirow[t]{3}{*}{ Limnocharis flava Buchenau } & Phak kanjong & ผักคันจอง & sawah-flower rush, sawah-lettuce, velvetleaf \\
\hline & Bak kanjong & บักคันจอง & \\
\hline & Phak pai & ผักพาย & \\
\hline \multicolumn{4}{|l|}{ Marsileaceae } \\
\hline Marsilea crenata C.Presl & Phak waen & ผักแว่น & pepperwort, water clover \\
\hline \multicolumn{4}{|l|}{ Meliaceae } \\
\hline Azadirachta indica A.Juss. var. indica & Phak ki nin & ผักคินิน & sadao India \\
\hline \multirow[t]{3}{*}{$\begin{array}{l}\text { Azadirachta indica A.Juss. var. siamensis } \\
\text { Valeton }\end{array}$} & Phak kadaw & ผักกะเดา & sweet neem, Thai neem \\
\hline & Yod kadaw & ยอดกะเดา & \\
\hline & Yod phak kadaw & ยอดผักกะเดา & \\
\hline \multicolumn{4}{|l|}{ Menispermaceae } \\
\hline \multirow[t]{2}{*}{ Cissampelos pareira $\mathrm{L}$. } & Bai maa noi & ใบหมาน้อย & velvetleaf \\
\hline & Maa noi & หมาน้อย & \\
\hline \multirow[t]{2}{*}{ Tiliacora triandra Diels } & Yaa nang & ย่านาง & \\
\hline & Bai yaa nang & ใบย่านาง & \\
\hline \multicolumn{4}{|l|}{ Menyanthaceae } \\
\hline Nymphoides indica (L.) Kuntze & Phak kanong ma & ผักกะหน่องม้า & banana-plant, water-snowflake \\
\hline \multicolumn{4}{|l|}{ Moraceae } \\
\hline \multirow[t]{2}{*}{ Artocarpus lacucha Roxb. } & Bak haad & บักหาด & monkey-jack, monkeyfruit \\
\hline & Maak haad & หมากหาด & \\
\hline \multicolumn{4}{|l|}{ Myrtaceae } \\
\hline Psidium guajava $\mathrm{L}$. & Bak sidaa noi & บักสึดานัอย & guava \\
\hline Syzygium cumini (L.) Skeels & Bak waa & บักหว่า & jambolan, Java-plum, Malabar-plum \\
\hline \multirow[t]{2}{*}{ Syzygium gratum (Wight) S.N.Mitra } & Phak mek & ผักเม็ก & \\
\hline & Maak mek & หมากเม็ก & \\
\hline \multicolumn{4}{|l|}{ Nymphaeaceae } \\
\hline \multirow[t]{2}{*}{ Nymphaea pubescens Willd. } & Phak sai bua & ผักสายบัว & red water-lily \\
\hline & Sai bua & สายบัว & \\
\hline \multicolumn{4}{|l|}{ Onagraceae } \\
\hline Ludwigia adscendens (L.) H.Hara & Phak phee phui & ผักผีพวย & water-primrose \\
\hline \multicolumn{4}{|l|}{ Opiliaceae } \\
\hline Melientha suavis Pierre & Phak waan paa & ผักหวานป่า & melientha \\
\hline \multicolumn{4}{|l|}{ Passifloraceae } \\
\hline \multirow[t]{2}{*}{ Adenia viridiflora Craib } & Bak saap & บักสาบ & \\
\hline & Phak saap & ผักสาบ & \\
\hline Passiflora foetida $\mathrm{L}$. & Tam nin farang & ตำนินฝรั่ง & $\begin{array}{l}\text { running pop, stinking passionflower, wild } \\
\text { water-lemon }\end{array}$ \\
\hline
\end{tabular}


Table 1 List of wild food plants (Continued)

\begin{tabular}{|c|c|c|c|}
\hline Poaceae & & & \\
\hline Bambusa sp. & Naw mai phai huwak & หน่อไม้ไผ่ฮวก & \\
\hline Bambusa bambos (L.) Voss & Naw mai phai paa & หน่อไม้ไผ่ป่า & giant thorny bamboo, spiny bamboo \\
\hline Vietnamosasa ciliata (A.Camus) T.Q.Nguyen & Naw jood & หน่อโจด & \\
\hline Pontederiaceae & & & \\
\hline Eichhornia crassipes (Mart.) Solms & Phak katok & ผักกะโดก & water-hyacinth \\
\hline & Phak paud & ผักปอด & \\
\hline Monochoria hastata (L.) Solms & Phak top & ผักตบ & $\begin{array}{l}\text { arrow-leaf monochoria, hastate-leaf- } \\
\text { pondweed }\end{array}$ \\
\hline & Phak top thai & ผักตบไทย & \\
\hline Monochoria vaginalis C.Presl & Phak e-hin & ผักอีฮีน & oval-leaf monochoria, pickerel-weed \\
\hline Rhamnaceae & & & \\
\hline Ziziphus mauritiana Lam. & Bak tan noi & บักทันน้อย & Indian jujube, Indian plum, Sour jujube \\
\hline Ziziphus oenoplia (L.) Mill. & Bak lep meuw & บักเล็บแมว & $\begin{array}{l}\text { jackal jujube, small-fruited jujube, wild } \\
\text { jujube }\end{array}$ \\
\hline & Maak lep meuw & หมากเล็บแมว & \\
\hline Rubiaceae & & & \\
\hline Oxyceros horridus Lour. & Bai kat kaaw & ใบคัดเค้า & \\
\hline Rothmannia wittii (Craib) Bremek. & Bak maaw & บักหม่อ & \\
\hline Rutaceae & & & \\
\hline Aegle marmelos Corrêa & Bak tuum & บักดูม & bael, belfruit-tree, golden-apple \\
\hline & Maak tuum & หมากตูม & \\
\hline & Yod maak tuum & ยอดหมากตูม & \\
\hline Sapindaceae & & & \\
\hline Lepisanthes rubiginosa (Roxb.) Leenh. & Bak huat kaa & บักหวดข่า & rusty sapindus \\
\hline Nephelium hypoleucum Kurz & Bak ngeuw & บักแงว & \\
\hline & Maak ngeuw & หมากแงว & \\
\hline Schleichera oleosa (Lour.) Oken & Bak kawe & บักค้อ & Ceylon-oak, lactree \\
\hline & Luk kawe & ลูกค้อ & \\
\hline & Maak kawe & หมากค้อ & \\
\hline Scrophulariaceae & & & \\
\hline Limnophila aromatica Merr. & Phak kayang & ผักกะแยง & swampleaf \\
\hline Umbelliferae & & & \\
\hline Centella asiatica (L.) Urb. & Phak nok & ผักหนอก & Asiatic pennywort, pennyweed, sheep-rot \\
\hline Oenanthe javanica DC. & Phak shi naam & ผักซึน้ำ & $\begin{array}{l}\text { Chinese-celery, Indian pennywort, water- } \\
\text { celery }\end{array}$ \\
\hline Zingiberaceae & & & \\
\hline Alpinia malaccensis C.Presl & Kaa paa & คาป่า & \\
\hline Curcuma singularis Gagnep. & Dok ka-jeeuw & ดอกกะเจียว & \\
\hline Curcuma sp. & Dok waun & ดอกหว่าน & \\
\hline Zygnemataceae & & & \\
\hline Spirogyra sp. & Taw & เทา & \\
\hline Unidentified & & & \\
\hline sp. 1 & Phak muad & ผักเหมือด & \\
\hline sp. 2 & Phak pe & ผักแป๋ & \\
\hline
\end{tabular}

Botanical family, scientific name, local Isaan name(s), English transliteration of local Isaan name(s) and English name(s). 


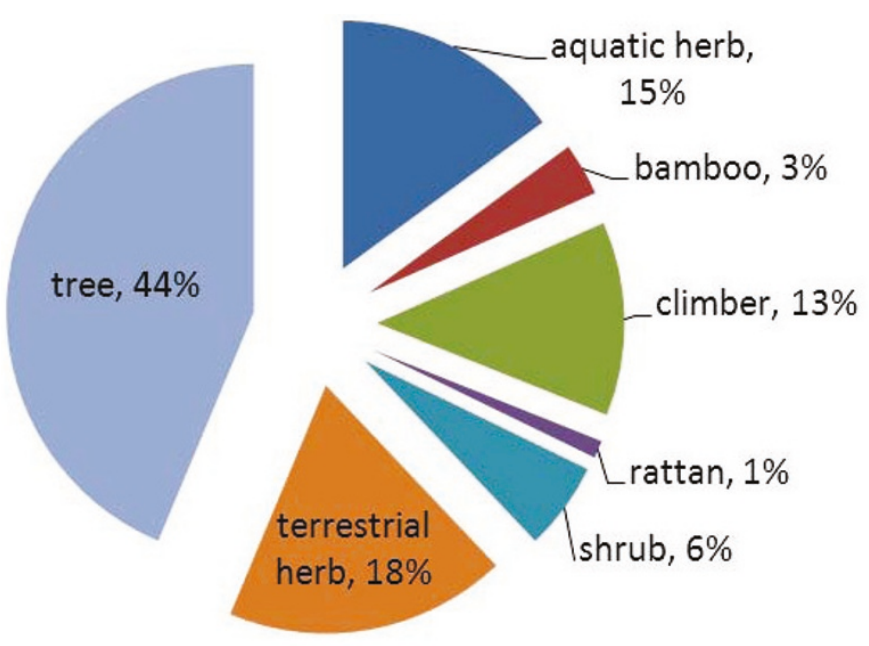

Figure 1 Growth forms of wild food plants.

locations, particularly rice fields, woods and home gardens. Forty percent of the wild food plants we documented grow in two different locations, $24 \%$ grow in three locations and $16 \%$ grow in four or more different locations. This can be explained, in part, by species being moved from one place to another facilitated by different degrees of management. This is consistent with the findings of Price [14] and Chanaboon et. al. [46], who reported the presence of wild food plant management practices in Northeast Thailand.

Out of the 38 tree species, $31(82 \%)$ are to be found in the secondary woody areas, $26(68 \%)$ in the rice fields, $22(58 \%)$ in home gardens and $22(58 \%)$ in upland fields. As discussed in the introductory section, the presence of trees is a common characteristic of rice ecosystems in Northeast Thailand. Trees grow in hillocks, shelters, tree rows and pond margins diversifying the habitats and facilitating the presence of climbers and other plants in the fields (Figure 2). Most trees are maintained in paddies due to their use value [9]. For instance, two thirds of the trees are medicinal (66\%) and, in addition, some provided timber and fuel.

\section{Multiplicity of uses, including parts used}

The edible parts of wild food plants vary from reproductive structures (flowers, fruits, seeds) to vegetative organs (leaves, shoots, stalks of flower, stems and sometimes the whole aerial part is consumed). For somewhat less than half of the plants only one part is edible (47\%), e.g. only the shoots of Neptunia oleracea are consumed. More specifically, for $25 \%$ of the plants two parts are eaten, which is the case of Adenia viridiflora (shoot and fruit). For 12\%, three parts are eaten, such as Senna sophera (shoot, flower and fruit). And for $16 \%$ of the plants, more than three parts are eaten as for Limnocharis flava (shoot, flower, stalk of flower and fruit).

In order to facilitate the analysis, eight categories of different parts consumed were established (see Figure 3):

1. Young shoots sprouting from roots, stems or tips of plants are consumed in 53\% of the wild food plants, such as Bambusa bambos, Senna sophera and Telosma minor. Shoots are widely consumed regardless of the growth form and life cycle of the plant.

2. Fruits, which can be eaten unripe and/or ripe depending on the plant, are consumed in $39 \%$ of plants, mainly trees and climbers. The fruit of Tamarindus indica is very popular both unripe (it is sour, seasoned with fish sauce and chili) and ripe (it is very sweet, eaten raw or its juice added to a dish of food).

3. Flowers or inflorescences are consumed for $24 \%$ of plants. Typical species are Dolichandrone serrulata and Curcuma singularis.

4. Whole aerial parts, including shoots, young leaves and tender stems, are consumed for $14 \%$ of plants. This is the case of many terrestrial and aquatic herbs including Limnophila aromatica and Glinus oppositifolius, with the exception of Cuscuta chinensis that is a climber.

5. Leaves, mainly eaten when young and tender as a raw vegetable or cooked in traditional dishes, are consumed for 9\% of plant species like the climber Cassytha filiformis and the tree Leucaena leucocephala.

6. Seeds are consumed for $7 \%$ of plants. For example, the seeds of Irvingia malayana are eaten roasted as a snack.

7. Stalks of flower or inflorescence are eaten in the case of $6 \%$ of the plants, including Nymphaea pubescens whose stalk is eaten raw as a side dish. 


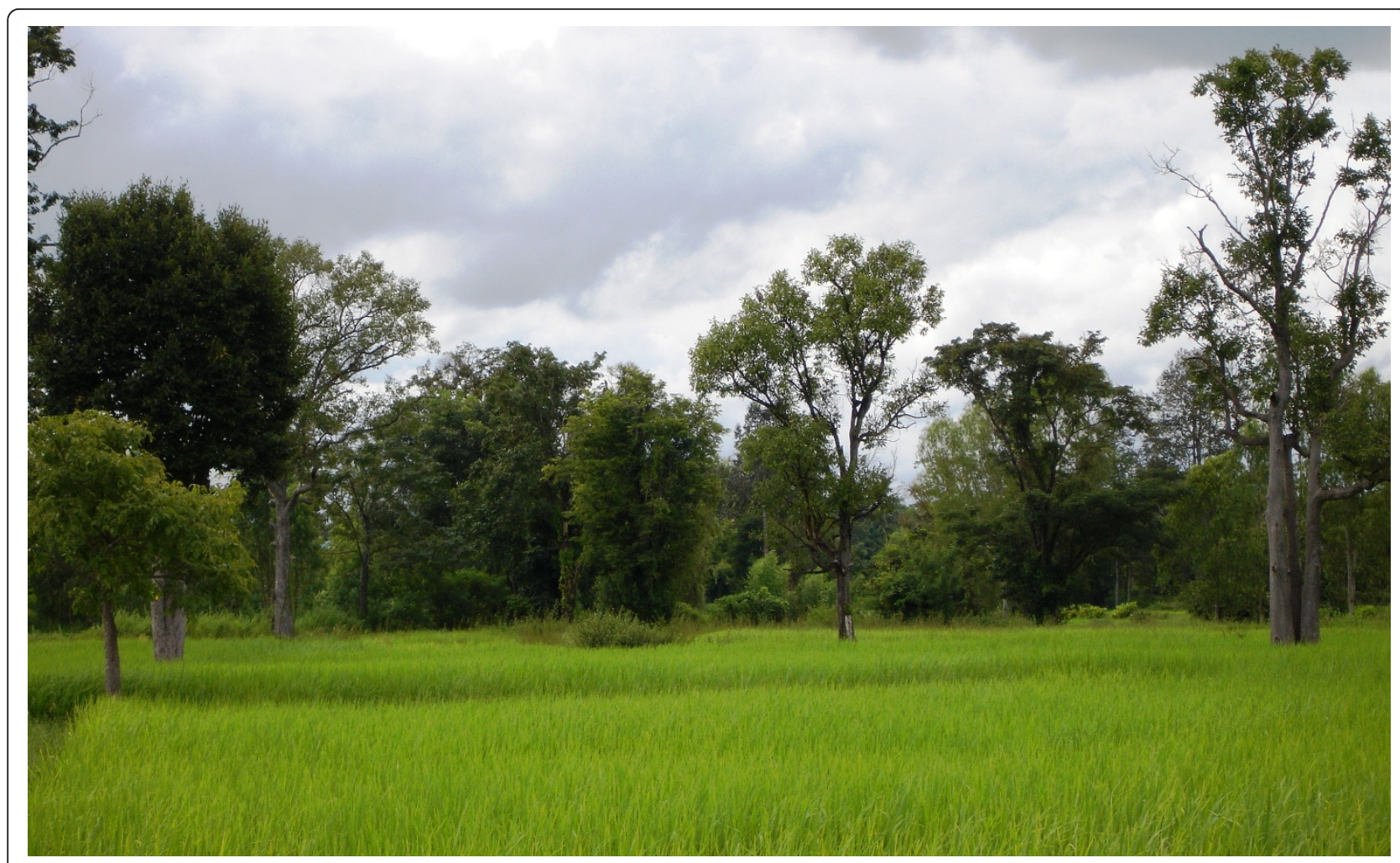

Figure $\mathbf{2}$ The presence of trees characterizes the rice fields in Northeast Thailand.

8. Stems are consumed for $5 \%$ of the plants, including the edible stems of the aquatic herb Ludwigia adscendens, the inner core of the trunk of the tree Borassus flabellifer (used to make sweets), and the rhizomes of the terrestrial herb Alpinia malaccensis.
More than two thirds of the wild food plants presented other uses besides food (71\%). Some $35 \%$ of plants had one additional use, while $26 \%$ of the plants had two additional uses, $7 \%$ had three additional uses, and three plants had four or more additional uses (see Figure 4).

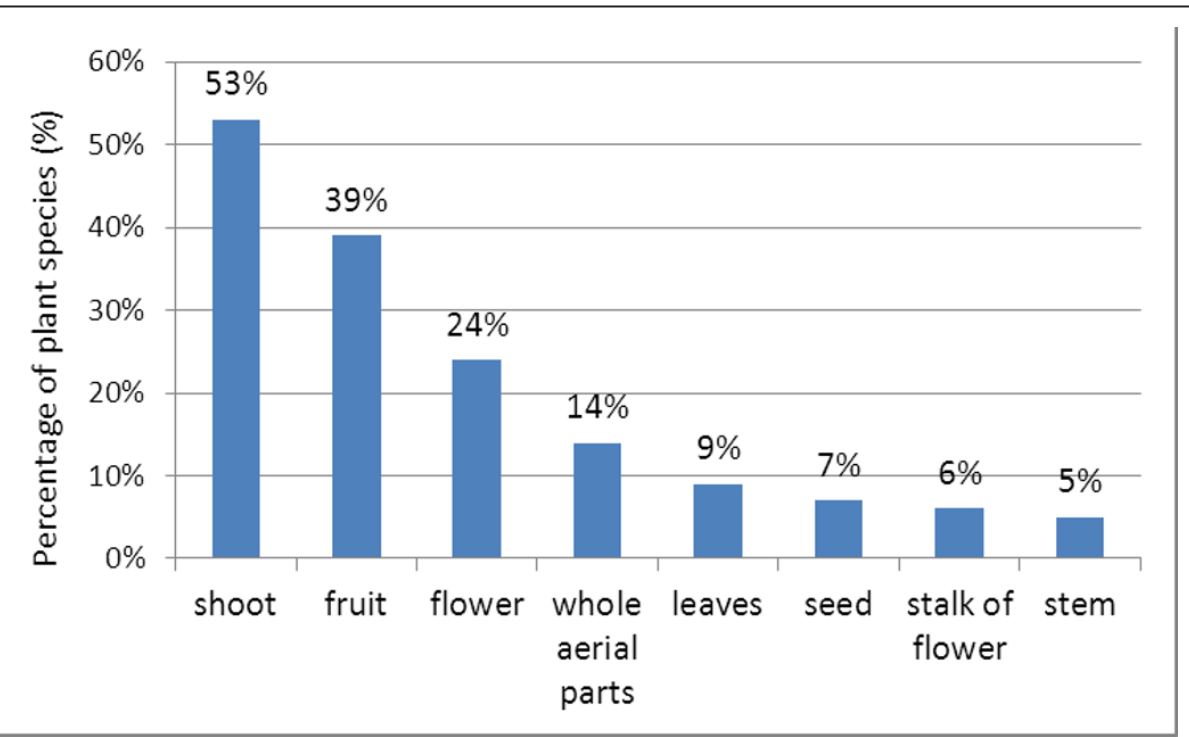

Figure 3 Edible parts of wild food plants 


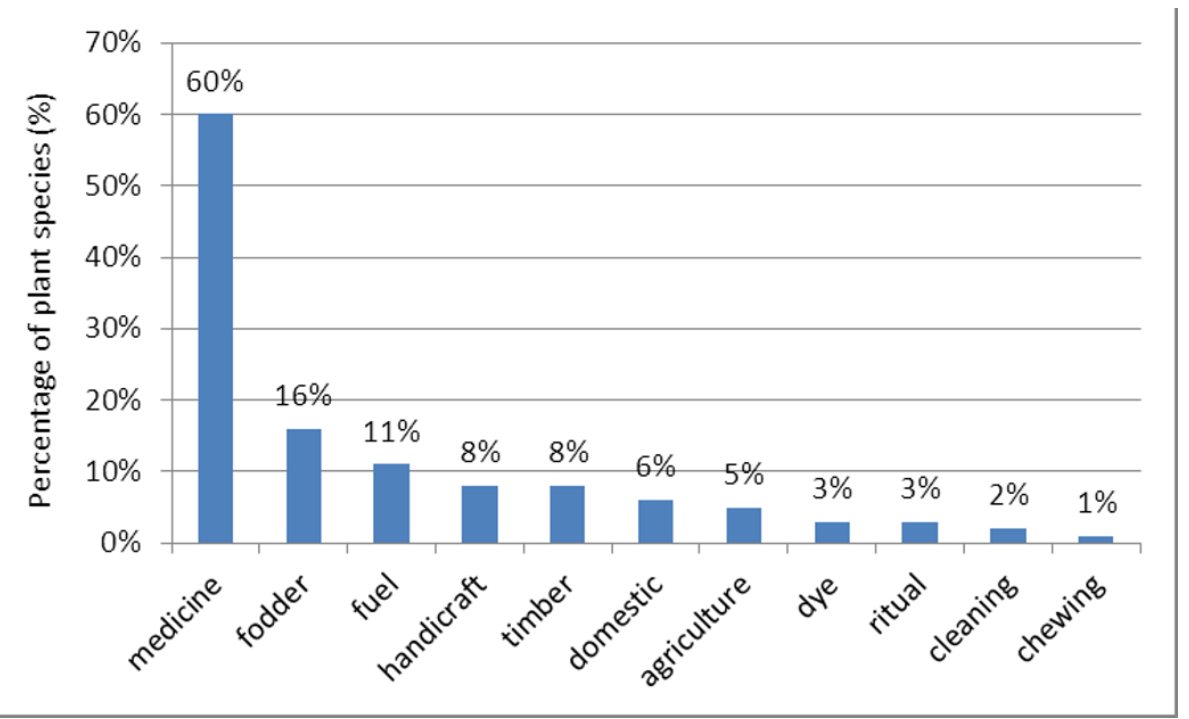

Figure 4 Additional uses of wild food plants

1. Medicine was the most widely mentioned additional use $(60 \%$ of the plants). Moreover, it is remarkable that out of the 30 plants with an additional use, 28 have medicinal uses. Some examples of medicinal plants are the herbs Centella asiatica and Ludwigia adscendens.

2. Fodder use was reported for $16 \%$ of the plants. More than half of these fodder plants ( 9 plants) are also regarded as medicine, such as Leucaena leucocephala and Coccinia grandis. Fodder plants are mostly herbs, trees and bamboos.

3. Twelve percent of the plants are used as fuel, like Nephelium hypoleucum and Cratoxylum formosum. Plants used as fuel were mainly trees growing in the rice fields and home gardens, many of them are also found in the woody areas.

4. Timber was reported for $8 \%$ of plants. It included trees such as Xylia xylocarpa and Spondias pinnata.

5. Eight percent of the plants are used for making local handicrafts. The three bamboo plant species are typically used in handicraft production such as in weaving hang mats. The wood of Artocarpus lacucha is used to make a traditional musical instrument similar to a xylophone called pong lang, which is regarded as the symbol of Kalasin Province.

6. Domestic use was reported for $6 \%$ of plants. For example the rattan Calamus sp. is used for making home utensils.

7. Five percent of the plants have auxiliary uses. The leaves of Azadirachta indica are utilized to make natural insecticide. Leucaena leucocephala (Leguminoseae) is used as fertilizer. All four plant species are also used as medicine.
8. Ritual use was reported for $3 \%$ of the plants. The Buddhist monks spread holy water using the leaves of Phyllanthus acidus. Villagers make curry with the young leaves of Aegle marmelos and give it to the monks in blessing ceremonies.

9. Dye was mentioned for $3 \%$ of plants used as natural colorants. The fruit of Tamarindus indica is used as dye for fish nets. The bark of Cratoxylum formosum is utilized to dye clothing.

10. Two plants are used for cleaning, for example Cassia siamea is used for making shampoo.

11. Only one plant is used for chewing. The bark of Artocarpus lacucha is chewed, sometimes with betle nut.

Consistent with the findings of Price [13] for Northeast Thailand, the importance of wild food plants as food-medicines is present in the current findings. The results indicate that these wild food-medicine plants are important not only for their curative properties, but also for their nutritional and preventive properties. Indeed, this overlapping role as a source of both food and medicine has been documented for farmers' use of wild plants in numerous parts of the world. For example in Vietnam [6], among the Hausa of Northern Nigeria [67], among Albanians and Southern Italians in Lucania [68], in the North West Bank, Palestine [69], and in the Inner Mongolian Autonomous Region, China [70]. Furthermore, undoubtedly, there is an overlap of food, medicine and animal feed, given that almost two thirds of fodder plants are also medicinal (9 out of 14 fodder plants). These results seem to follow the pattern of Ogle et. al. [6] who discussed the multiple functions of wild food plants in Vietnam. 
Table 2 Growth form, life cycle, growth location, edible parts and additional uses of wild food plants.

\begin{tabular}{|c|c|c|c|c|}
\hline Scientific name & $\begin{array}{l}\text { Growth form/ } \\
\text { Life cycle }\end{array}$ & Growth location(s) & Edible part(s) & Additional use(s) \\
\hline \multicolumn{5}{|l|}{ Aizoaceae } \\
\hline Glinus oppositifolius (L.) Aug.DC. & $\begin{array}{l}\text { terrestrial herb/ } \\
\text { A }\end{array}$ & rice field & whole aerial parts & \\
\hline \multicolumn{5}{|l|}{ Amaranthaceae } \\
\hline Amaranthus viridis $L$. & $\begin{array}{l}\text { terrestrial herb/ } \\
\text { A }\end{array}$ & rice field, home garden & $\begin{array}{l}\text { shoot, whole aerial } \\
\text { parts }\end{array}$ & medicine, fodder \\
\hline \multicolumn{5}{|l|}{ Anacardiaceae } \\
\hline Mangifera caloneura Kurz & tree/P & woods, upland fields & fruit & timber, domestic \\
\hline Spondias pinnata Kurz & tree/P & $\begin{array}{l}\text { rice field, home garden, woods, } \\
\text { upland fields, roadside }\end{array}$ & leaves, fruit & medicine, timber \\
\hline \multicolumn{5}{|l|}{ Annonaceae } \\
\hline Polyalthia debilis Finet \& Gagnep. & shrub/P & home garden, woods, upland fields & fruit & medicine \\
\hline Polyalthia evecta Finet \& Gagnep. & tree/P & home garden, woods, upland fields & fruit & medicine \\
\hline Uvaria pierrei Finet \& Gagnep. & climber/P & home garden, woods & fruit & \\
\hline \multicolumn{5}{|l|}{ Araceae } \\
\hline Amorphophallus sp. & $\begin{array}{l}\text { terrestrial herb/ } \\
\text { A }\end{array}$ & rice field, woods & shoot & \\
\hline \multicolumn{5}{|l|}{ Araliaceae } \\
\hline Irvingia malayana Oliver & tree/P & rice field, woods & seed & $\begin{array}{l}\text { medicine, timber, fuel, } \\
\text { fodder }\end{array}$ \\
\hline \multicolumn{5}{|l|}{ Arecaceae } \\
\hline Borassus flabellifer $\mathrm{L}$. & tree/P & $\begin{array}{l}\text { rice field, home garden, upland } \\
\text { fields }\end{array}$ & flower, fruit, stem & medicine, handicraft \\
\hline Calamus sp. & rattan/P & $\begin{array}{l}\text { rice field, home garden, upland } \\
\text { fields }\end{array}$ & shoot, fruit & domestic \\
\hline \multicolumn{5}{|l|}{ Asclepiadaceae } \\
\hline Telosma minor Craib & climber/P & rice field, home garden, woods & shoot, flower, fruit & medicine \\
\hline \multicolumn{5}{|l|}{ Basellaceae } \\
\hline Basella rubra L. & climber/P & $\begin{array}{l}\text { rice field, home garden, woods, } \\
\text { upland fields }\end{array}$ & shoot & medicine \\
\hline \multicolumn{5}{|l|}{ Bignoniaceae } \\
\hline Dolichandrone serrulata Seem. & tree/P & woods & flower & medicine \\
\hline Oroxylum indicum Vent. & tree/P & $\begin{array}{l}\text { rice field, home garden, woods, } \\
\text { upland fields }\end{array}$ & shoot, flower, fruit & medicine \\
\hline \multicolumn{5}{|l|}{ Burseraceae } \\
\hline Canarium subulatum Guillaumin & tree/P & woods & seed & medicine, fuel, fodder \\
\hline \multicolumn{5}{|l|}{ Campanulaceae } \\
\hline Lobelia begonifolia Wall. & $\begin{array}{l}\text { terrestrial herb/ } \\
\text { A }\end{array}$ & rice field & whole aerial parts & \\
\hline Lobelia sp. & $\begin{array}{l}\text { terrestrial herb/ } \\
\text { A }\end{array}$ & rice field & whole aerial parts & \\
\hline \multicolumn{5}{|l|}{ Clusiaceae } \\
\hline $\begin{array}{l}\text { Cratoxylum formosum (Jack) Benth. \& } \\
\text { Hook.f. ex Dyer }\end{array}$ & tree/P & rice field, home garden, woods & shoot, leaves, flower & fuel, domestic, dye \\
\hline Garcinia cowa Roxb. & tree/P & rice field, woods & shoot, fruit & \\
\hline \multicolumn{5}{|l|}{ Compositae } \\
\hline Blumea balsamifera DC. & $\begin{array}{l}\text { terrestrial herb/ } \\
\mathrm{P}\end{array}$ & rice field & shoot & medicine, ritual \\
\hline Emilia sonchifolia (L.) DC. & $\begin{array}{l}\text { terrestrial herb/ } \\
\text { A }\end{array}$ & rice field & whole aerial parts & \\
\hline
\end{tabular}


Table 2 Growth form, life cycle, growth location, edible parts and additional uses of wild food plants. (Continued)

\begin{tabular}{|c|c|c|c|c|}
\hline Convolvulaceae & & & & \\
\hline Cuscuta chinensis Lam. & climber/A & rice field, home garden, roadside & whole aerial parts & \\
\hline Ipomoea aquatica Forssk. & $\begin{array}{l}\text { terrestrial herb/ } \\
\mathrm{P}\end{array}$ & roadside & shoot & medicine, fodder \\
\hline \multicolumn{5}{|l|}{ Cucurbitaceae } \\
\hline Coccinia grandis (L.) Voigt & climber/P & home garden, roadside & shoot, flower, fruit & medicine, fodder \\
\hline Momordica charantia L. & climber/A & rice field, home garden & shoot, fruit & medicine \\
\hline \multicolumn{5}{|l|}{ Ebenaceae } \\
\hline Diospyros rhodocalyx Kurz & tree/P & rice field, home garden & fruit & medicine \\
\hline \multicolumn{5}{|l|}{ Euphorbiaceae } \\
\hline Phyllanthus acidus (L.) Skeels & tree/P & rice field, home garden & shoot, fruit & medicine, ritual \\
\hline \multicolumn{5}{|l|}{ Fagaceae } \\
\hline Castanopsis sp. & tree/P & woods & seed & medicine, fuel \\
\hline \multicolumn{5}{|l|}{ Gnetaceae } \\
\hline Gnetum sp. & tree/P & rice field, woods & seed & \\
\hline \multicolumn{5}{|l|}{ Hydrocharitaceae } \\
\hline Ottelia alismoides (L.) Pers. & aquatic herb/P & rice field, swamps & whole aerial parts & \\
\hline \multicolumn{5}{|l|}{ Hydrophyllaceae } \\
\hline Hydrolea zeylanica (L.) J.Vahl & aquatic herb/A & rice field, swamps & shoot, flower & medicine \\
\hline \multicolumn{5}{|l|}{ Lauraceae } \\
\hline Cassytha filiformis L. & climber/P & rice field, home garden & $\begin{array}{l}\text { leaves, flower, stalk of } \\
\text { flower, stem }\end{array}$ & \\
\hline \multicolumn{5}{|l|}{ Lecythidaceae } \\
\hline Barringtonia acutangula (L.) Gaertn. & tree/P & rice field, home garden & shoot, flower & \\
\hline Careya arborea Roxb. & tree/P & woods, upland fields & shoot, flower & \\
\hline \multicolumn{5}{|l|}{ Leguminosae } \\
\hline Adenanthera pavonina $\mathrm{L}$. & tree/P & home garden, woods & shoot, flower & \\
\hline Cajanus cajan (L.) Millsp. & shrub/P & $\begin{array}{l}\text { rice field, home garden, upland } \\
\text { fields }\end{array}$ & seed & medicine \\
\hline Cassia siamea Lam. & tree/P & $\begin{array}{l}\text { rice field, home garden, woods, } \\
\text { upland fields, roadside }\end{array}$ & shoot & medicine, cleaning \\
\hline Dialium cochinchinense Pierre & tree/P & woods, upland fields & fruit & medicine, domestic \\
\hline Leucaena leucocephala (Lam.) de Wit & tree/P & $\begin{array}{l}\text { rice field, home garden, woods, } \\
\text { upland fields, roadside }\end{array}$ & shoot, leaves, fruit & $\begin{array}{l}\text { medicine, fuel, fodder, } \\
\text { auxiliary }\end{array}$ \\
\hline Neptunia javanica Miq. & $\begin{array}{l}\text { terrestrial herb/ } \\
\text { P }\end{array}$ & home garden, roadside, swamps & shoot & \\
\hline Neptunia oleracea Lour. & aquatic herb/p & rice field, swamps & shoot & \\
\hline Pithecellobium dulce (Roxb.) Benth. & tree/P & rice field, home garden, roadside & fruit & fuel \\
\hline Senna sophera (L.) Roxb. & shrub/P & rice field, home garden & shoot, flower, fruit & medicine \\
\hline Sindora siamensis Teijsm. ex Miq. & tree/P & rice field, woods, upland fields & fruit & medicine \\
\hline Tamarindus indica L. & tree/P & $\begin{array}{l}\text { rice field, home garden, woods, } \\
\text { upland fields, roadside }\end{array}$ & shoot, fruit & $\begin{array}{l}\text { medicine, timber, fuel, } \\
\text { fodder, dye, cleaning }\end{array}$ \\
\hline $\begin{array}{l}\text { Xylia xylocarpa Taub. var kerrii (Craib } \\
\text { \& Hutch) I.C. Nielsen }\end{array}$ & tree/P & rice field, woods, upland fields & seed & medicine, timber \\
\hline \multicolumn{5}{|l|}{ Liliaceae } \\
\hline Asparagus racemosus Willd. & $\begin{array}{l}\text { terrestrial herb/ } \\
\mathrm{P}\end{array}$ & $\begin{array}{l}\text { rice field, home garden, woods, } \\
\text { upland fields }\end{array}$ & shoot & \\
\hline \multicolumn{5}{|l|}{ Limnocharitaceae } \\
\hline Limnocharis flava Buchenau & aquatic herb/A & rice field, swamps & $\begin{array}{l}\text { shoot, flower, stalk of } \\
\text { flower, fruit }\end{array}$ & \\
\hline
\end{tabular}


Table 2 Growth form, life cycle, growth location, edible parts and additional uses of wild food plants. (Continued)

\begin{tabular}{|c|c|c|c|c|}
\hline Marsileaceae & & & & \\
\hline Marsilea crenata C.Presl & aquatic herb/P & rice field & whole aerial parts & medicine \\
\hline \multicolumn{5}{|l|}{ Meliaceae } \\
\hline Azadirachta indica A.Juss. var. indica & tree/P & $\begin{array}{l}\text { rice field, home garden, woods, } \\
\text { upland fields }\end{array}$ & shoot, flower & medicine, auxiliary \\
\hline $\begin{array}{l}\text { Azadirachta indica A.Juss. var. } \\
\text { siamensis Valeton }\end{array}$ & tree/P & rice field, home garden & shoot, flower & medicine, timber, auxiliary \\
\hline \multicolumn{5}{|l|}{ Menispermaceae } \\
\hline Cissampelos pareira $\mathrm{L}$. & climber/P & home garden, woods, upland fields & shoot, leaves & medicine \\
\hline Tiliacora triandra Diels & climber/P & home garden, woods, upland fields & shoot, leaves & medicine, domestic \\
\hline \multicolumn{5}{|l|}{ Menyanthaceae } \\
\hline Nymphoides indica (L.) Kuntze & aquatic herb/P & swamps & shoot & \\
\hline \multicolumn{5}{|l|}{ Moraceae } \\
\hline Artocarpus lacucha Roxb. & tree/P & rice field, woods, upland fields & fruit & $\begin{array}{l}\text { medicine, handicraft, } \\
\text { chewing }\end{array}$ \\
\hline \multicolumn{5}{|l|}{ Myrtaceae } \\
\hline Psidium guajava $\mathrm{L}$. & tree/P & $\begin{array}{l}\text { rice field, home garden, woods, } \\
\text { upland fields, roadside }\end{array}$ & fruit & medicine \\
\hline Syzygium cumini (L.) Skeels & tree/P & $\begin{array}{l}\text { rice field, home garden, woods, } \\
\text { upland fields }\end{array}$ & fruit & medicine \\
\hline Syzygium gratum (Wight) S.N.Mitra & tree/P & $\begin{array}{l}\text { rice field, home garden, woods, } \\
\text { upland fields }\end{array}$ & shoot, fruit & \\
\hline \multicolumn{5}{|l|}{ Nymphaeaceae } \\
\hline Nymphaea pubescens Willd. & aquatic herb/P & rice field, swamps & stalk of flower & medicine \\
\hline \multicolumn{5}{|l|}{ Onagraceae } \\
\hline Ludwigia adscendens (L.) H.Hara & aquatic herb/A & rice field, swamps & shoot, leaves, stem & medicine, fodder \\
\hline \multicolumn{5}{|l|}{ Opiliaceae } \\
\hline Melientha suavis Pierre & tree/P & woods & shoot, flower & \\
\hline \multicolumn{5}{|l|}{ Passifloraceae } \\
\hline Adenia viridiflora Craib & climber/A & woods, upland fields & shoot, fruit & medicine \\
\hline Passiflora foetida L. & climber/A & $\begin{array}{l}\text { rice field, home garden, upland } \\
\text { fields, roadside }\end{array}$ & shoot, fruit & \\
\hline \multicolumn{5}{|l|}{ Poaceae } \\
\hline Bambusa sp. & bamboo/P & rice field, home garden, woods & shoot & fuel, handicraft, fodder \\
\hline Bambusa bambos (L.) Voss & bamboo/P & rice field, woods, upland fields & shoot & handicraft, fodder \\
\hline $\begin{array}{l}\text { Vietnamosasa ciliata (A.Camus) T.Q. } \\
\text { Nguyen }\end{array}$ & bamboo $\mathrm{P}$ & woods & shoot & handicraft, fodder \\
\hline \multicolumn{5}{|l|}{ Pontederiaceae } \\
\hline Eichhornia crassipes (Mart.) Solms & aquatic herb/P & rice field, swamps & shoot, flower & handicraft, fodder \\
\hline Monochoria hastata (L.) Solms & $\begin{array}{l}\text { aquatic herb/A- } \\
\mathrm{P}\end{array}$ & rice field, swamps & $\begin{array}{l}\text { shoot, flower, stalk of } \\
\text { flower }\end{array}$ & handicraft, fodder \\
\hline Monochoria vaginalis C.Presl & $\begin{array}{l}\text { aquatic herb/A- } \\
\text { P }\end{array}$ & rice field, swamps & whole aerial parts & medicine \\
\hline \multicolumn{5}{|l|}{ Rhamnaceae } \\
\hline Ziziphus mauritiana Lam. & tree/P & $\begin{array}{l}\text { rice field, home garden, woods, } \\
\text { upland fields, roadside }\end{array}$ & fruit & timber, fuel, dye \\
\hline Ziziphus oenoplia (L.) Mill. & shrub/P & rice field, home garden, woods & fruit & medicine \\
\hline \multicolumn{5}{|l|}{ Rubiaceae } \\
\hline Oxyceros horridus Lour. & shrub/P & home garden, woods & shoot, leaves & medicine \\
\hline Rothmannia wittii (Craib) Bremek. & tree/P & woods & fruit & \\
\hline
\end{tabular}


Table 2 Growth form, life cycle, growth location, edible parts and additional uses of wild food plants. (Continued)

\begin{tabular}{|c|c|c|c|c|}
\hline \multicolumn{5}{|l|}{ Rutaceae } \\
\hline Aegle marmelos Corrêa & tree/P & $\begin{array}{l}\text { rice field, home garden, woods, } \\
\text { upland fields }\end{array}$ & shoot, fruit & medicine, ritual \\
\hline \multicolumn{5}{|l|}{ Sapindaceae } \\
\hline Lepisanthes rubiginosa (Roxb.) Leenh. & tree/P & rice field, home garden, woods & fruit & medicine \\
\hline Nephelium hypoleucum Kurz & tree/P & home garden, woods, upland fields & fruit & medicine, fuel \\
\hline Schleichera oleosa (Lour.) Oken & tree/P & rice field, upland fields & fruit & \\
\hline \multicolumn{5}{|l|}{ Scrophulariaceae } \\
\hline Limnophila aromatica Merr. & $\begin{array}{l}\text { terrestrial herb/ } \\
\text { A }\end{array}$ & rice field, home garden & whole aerial parts & medicine \\
\hline \multicolumn{5}{|l|}{ Umbelliferae } \\
\hline Centella asiatica (L.) Urb. & $\begin{array}{l}\text { terrestrial herb/ } \\
\mathrm{P}\end{array}$ & rice field, home garden & whole aerial parts & medicine \\
\hline Oenanthe javanica DC. & $\begin{array}{l}\text { terrestrial herb/ } \\
\mathrm{P}\end{array}$ & swamps & shoot & \\
\hline \multicolumn{5}{|l|}{ Zingiberaceae } \\
\hline Alpinia malaccensis C.Presl & $\begin{array}{l}\text { terrestrial herb/ } \\
\mathrm{P}\end{array}$ & rice field, woods & shoot, flower, stem & medicine, auxiliary \\
\hline Curcuma singularis Gagnep. & $\begin{array}{l}\text { terrestrial herb/ } \\
\mathrm{P}\end{array}$ & woods & flower & medicine \\
\hline Curcuma sp. & $\begin{array}{l}\text { terrestrial herb/ } \\
\mathrm{P}\end{array}$ & woods & flower, stalk of flower & medicine \\
\hline \multicolumn{5}{|l|}{ Zygnemataceae } \\
\hline Spirogyra sp. & aquatic herb/A & rice field, swamps & whole aerial parts & medicine \\
\hline \multicolumn{5}{|l|}{ Unidentified } \\
\hline sp. 1 & tree/P & woods, upland fields & shoot & medicine \\
\hline sp. 2 & aquatic herb/A & swamps & shoot & medicine, fodder \\
\hline
\end{tabular}

For life cycle $P$ is perennial and $A$ is annual.

Villagers also mentioned additional uses of wild food plants related to the ecological services they provide. For instance, they commented that the aquatic herb Monochoria hastata, which is regarded as a weed of rice fields, provides shade for fish. Additionally, many trees were acknowledged as habitats of red ants and other edible insects. Fish and insects, among other animals, are also gathered from the rice fields constituting an important part of the local diet.

Growth form, growth location, edible parts and additional uses of wild food plants are presented in Table 2.

\section{Conclusions}

This study shows the remarkable importance of anthropogenic ecosystems in providing wild food plants. This is reflected in the great diversity of plants found, contributing to the food and nutritional security of rice farmers in Kalasin, Northeast Thailand. The data compiled in this study shows that the majority of wild food plants grow in the different aquatic, semi-aquatic and terrestrial sub-systems offered by rice agro-ecosystems. Trees presented more plants than other growth forms, constituting an important feature of different terrestrial sub- systems of the paddies, such as hillocks, tree rows and shelters. Many important plants are aquatic and terrestrial herbs, as well as climbers. Both annual and perennial species are present in significant numbers.

One of the main findings is that most wild food plants are found in multiple locations, and more than half of them grow either in rice fields and home gardens, rice fields and woods, home gardens and woods, or rice fields, home gardens and woods. No plants were exclusive to home gardens and very few plants were exclusive to woods and rice fields. From these results we assert that farmers play an active role in managing many of these plants, for example, transplanting them from the woods to the fields or to home gardens, making them available in those anthropogenic places located closer to their house and village. This assertion follows the patterns proposed by the "botanical dietary paradox", which clarifies the use of so many wild food plants by farmers in that when deforestation occurs, farmers change to gathering new wild food plants closer to home, including the weeds of agriculture $[8,38]$.

Another major point to note from the results of this research is that more than half of the wild food plants 
have many edible parts, and more than two thirds of them have additional uses. Shoots, sprouting from the tips of plants, stems or roots, were the most widely cited as consumed regardless of the growth form or life cycle of the plant. Fruits were also common, particularly collected from trees and climbers. Wild food plants presented more than eleven additional uses, accentuating their overall relevance for rice farmers. The most common additional use was for medicine.

The data compiled in this study highlights the necessity to better understand the role of anthropogenic ecosystems in providing wild food plant resources. Further research needs to be carried out on the seasonal quantification of their environmental availability, as well as the location of actual gathering events. Finally, research on transplanting and other management practices would allow us to better comprehend the distribution of these plants in the different ecosystems.

\begin{abstract}
Acknowledgements
This study belongs to the multidisciplinary project 'Wild' Vegetables, Fruits and Mushrooms in Rural Household Well-being: An In-depth Multidisciplinary Village Study in Northeast Thailand on which Dr. Lisa Price is the Principal Investigator, funded by the Neys van Hoogstraaten Foundation. This study was carried out with a UNESCO-L'ORÉAL Fellowship for Young Women in Sciences and the economic support of Het Schure-Beijerinck-Popping Fonds from the Royal Netherlands Academy of Arts and Sciences (The Netherlands). Part of the research was carried out under the auspices of Weed Sciences Group of the International Rice Research Institute (IRRI). We are grateful to Eelco Meuter from Wageningen University who supported us with the setting up of the database and Teerapong Wongyao who helped us with the Thai script. Our thanks are extended to Chusie Trisonthi from the Department of Biology, Faculty of Science, Chiang Mai University, as well as Suttira Khoomgratok and Komgrit Wongpakam from Walai Rukhavej Botanical Research Institute (WRBRI) of Mahasarakham University, who did the taxonomical identification of the plants. Field assistance provided, by Paul Peters, Paitoon Nakvanich, Wasana Pupak, Siriporn Kotawinon and Bangon Phetsugan is deeply appreciated. A special thank you to the Kalasin Province Cultural Office and Dr. Pairot Petsunghan for his facilitation. We are especially indebted to the Kalasin farmers who provided us not only with valuable information during this research, but also with their hospitality and care.
\end{abstract}

\section{Author details}

${ }^{1}$ Centre for Crop Systems Analysis, Department of Plant Sciences, Wageningen University, Wageningen, The Netherlands. '2Department of Social Sciences, Wageningen University, Wageningen, The Netherlands. ${ }^{3}$ Department of Anthropology, Oregon State University, Corvallis Oregon, USA.

\section{Authors' contributions}

GCG and LP designed, conducted data collection and interpreted the data. GCG performed the data processing and analysis. The taxonomic revision was coordinated by GCG and LP Literature retrieval was done by both authors. GCG drafted the manuscript, which was revised by LP All authors read and approved the final manuscript.

\section{Competing interests}

The authors declare that they have no competing interests.

Received: 21 June 2011 Accepted: 8 November 2011

Published: 8 November 2011

\section{References}

1. Cruz-García G, Ertug F: Wild food plants in the present and past. In Plants and people: choices and diversity through time. Edited by: Chevalier A, Marinova E, Peña-Chocarro L. European Science Foundation, Oxbow; , Forthcoming.[Anderson PC, Peña-Chocarro L (Series Editor) ESF EARTH Monograph Series].

2. Bharucha Z, Pretty J: The roles and values of wild foods in agricultural systems. Philosophical Transactions of the Royal Society 2010, 365:2913-2926.

3. Scoones I, Melnyk M, Pretty JN: The hidden harvest: wild foods and agricultural systems: a literature review and annotated bibliography, compiled by lan Scoones, Mary Melnyk, Jules N. Pretty London: International Institute for Environment and Development; 1992.

4. IRRI: IRRI's Environmental Agenda-an approach toward sustainable development Los Baños: International Rice Research Institute; 2004

5. Ogle BM, Dao HTA, Mulokozi G, Hambraeus L: Micronutrient composition and nutritional importance of gathered vegetables in Vietnam. International Journal of Food Sciences and Nutrition 2001, 52:485-499.

6. Ogle BM, Tuyet HT, Duyet HN, Dung NNX: Food, feed or medicine: the multiple functions of edible wild plants in Vietnam. Economic Botany 2003, 57:103-117.

7. Kosaka Y: Plant diversity in paddy field landscape in Savannakhet Province, Laos. Kyoto University, Graduate School of Asian and African Area Studies; 2006.

8. Price L, Ogle BM: Gathered indigenous vegetables in Mainland Southeast Asia: a gender asset. In Gender and natural resource management: livelihoods, mobility and interventions. Edited by: Resurreccion BP, Resurreccion BP, Elmhirst R. Earthscan; 2008:

9. Grandstaff S, Grandstaff TB, Rathakette P, Thomas DE, Thomas JK: Trees in paddy fields in Northeast Thailand. In Traditional agriculture in Southeast Asia A human ecology perspective. Edited by: Marten GE. London: Westview Press; 1986:273-292.

10. Lyndon W, Yongvanit S: Biological diversity and community lore in Northeastern Thailand. Journal of Ethnobiology 1995, 15:71-87.

11. Moreno-Black G, Price LL: The marketing of gathered food as an economic strategy of women in Northeastern Thailand. Human Organization 1993, 52:398-405.

12. Moreno-Black G, Somnasang P: In times of plenty and times of scarcity: non-domesticated food in Northeastern Thailand. Ecology of Food and Nutrition 2000, 38:563-586.

13. Price $L$ : Wild food plants in farming environments with special reference to Northeast Thailand, food as functional and medicinal, and the social roles of women. In Eating and healing, traditional food as medicine. Edited by: Pieroni A, Price L. NY: Food Products Press, an imprint of The Haworth Press, Inc:; 2005:406.

14. Price LL: Wild plant food in agricultural environments: a study of occurrence, management, and gathering rights in Northeast Thailand. Human Organization 1997, 56:209-221.

15. Parnwell MJG: Rural poverty, development and the environment: the case of North-East Thailand. Journal of Biogeography 1988, 15:199-208.

16. Wijnhoud JD: Nutrient budgets, soil fertility management and livelihood analyses in Northeast Thailand. A basis for integrated rural development strategies in developing countries. Wageningen University; 2007.

17. Vityakon P, Subhadhira S, Limpinuntana V, Srila S, Trelo-Ges V, Sriboonlue V: From forest to farmfields: changes in land use in undulating terrain of Northeast Thailand at different scales during the past century. Southeast Asian Studies 2004, 41:444-472.

18. Prachaiyo B: Farmers and forests: a changing phase in Northeast Thailand. Southeast Asian Studies 2000, 38:3-156.

19. Tipraqsa P: Opportunities and constraints of integrated farming system in Northeast Thailand. A case study of the Huai Nong lan catchment, Khon Kaen province Cuvillier Verlag Göttingen; 2006.

20. Asian Development Bank (ADB): Asia's crisis plagues the poor. ADB Online News Release No. 28/1999 Manila, Philippines: Asian Development Bank; 1999.

21. Prapertchob P: Human resources and the economy of the Northeast region of Thailand. In Proceedings of the Planning Workshop "Ecoregional approaches to natural resource management in the Korat Basin, Northeast Thailand: towards further research collaboration"; 26-29 October 1999; Khon Kaen. Edited by: Kam SP, Hoanh CT, Trébuil G, Hardy B. International Rice Research Institute; 2001: 
22. Office of Agricultural Economics: Agricultural statistics of Thailand: crop year 1996/1997 Bangkok: Office of Agricultural Economics, Ministry of Agriculture and Cooperatives; 1998.

23. National Statistical Office of Thailand: The 2000 population and housing census. Changwat Kalasin Bangkok, Thailand: National Statistical Office, Office of the Prime Minister; 2001.

24. WorldClim - Global Climate Data. [http://worldclim.org/].

25. Ngarmsak T: Status and nutritional importance of unconventional food crops in Thai diets Bangkok: Regional Office for Asia and the Pacific, Food and Agriculture Organization of the United Nations; 1987.

26. Wanida S: Major non-wood forest products of Thailand Bangkok: Royal Forestry Department; 1995

27. Somnasang P, Moreno-Black G: Knowing, gathering and eating: knowledge and attitudes about wild food in an Asian village in Northeastern Thailand. Journal of Ethnobiology 2000, 20:197-216.

28. Price L: Farm women's rights and roles in wild plant food gathering and management in North-East Thailand. In Women and plants Gender relations in biodiversity management and conservation. Edited by: Howard P. London 2003:101-114.

29. Moreno-Black G, Somnasang P, Thamthawan S: Women in Northeastern Thailand: preservers of botanical diversity. Indigenous Knowledge and Development Monitor 1994, 2:24

30. Somnasang P: Indigenous food use: gender issues in rural Northeast Thailand. University of Oregon; 1996.

31. Price $L L$ : Women's wild plant food entitlements in Thailand's agricultural Northeast. University of Oregon, Anthropology Department; 1993.

32. Price $L L:$ Women at the center: wild plant food use, gathering rights and management in disturbed farming environments. In Proceedings of the Forum "Comparing and contrasting different research approaches on semi and uncultivated plant food"; Harare, Zimbabwe. Edited by: Macharaire V. International Development Research Center of Canada (IDRC) and the Community Technology Development Trust (CTDT) of Zimbabwe; 2001:.

33. Somnasang P, Moreno-Black G, Chusil K: Indigenous knowledge of wild food hunting and gathering in North-east Thailand. Food and Nutrition Bulletin 1998, 19:359-365.

34. Somnasang $P$, Rathakette $P$, Rathanapanya $S$ : The role of natural foods in North East Thailand. Proceedings of the Nutrition and Forestry Workshop; 1821 October 1988; Khon Kaen University, Thailand 1988.

35. Coomklang A, Sakulcoo S, Prakanong R: Food dishes in Northeast Thailand Bangkok: Institute for Agricultural Training, Rajchamongchol Technical University, Ministry of Education; 2000

36. Price $L$ : The fields are full of gold: women's marketing of wild foods from rice fields in Southeast Asia and the impacts of pesticides and integrated pest management. In Women farmers and commercial ventures: increasing food security in developing countries. Edited by: Spring A. Colorado and London: Lynne Rienner Publishers; 2000:.

37. Sapjareun P, Kumkrang A, Deewised K: Local vegetables in Isaan Bangkok: Foundation of Thai Medicine Development; 2004.

38. Ogle BM, Grivetti LE: Legacy of the chameleon: edible wild plants in the Kingdom of Swaziland, Southern Africa. A cultural, ecological, nutritional study. Ecology of Food and Nutrition 1985, 17:1-40.

39. Saowakontha S, Kunarattanapruk K, Ayuwat D, Chokkanapitak J, Uttamavatin P, Lowirakorn S: Dependancy on forest and tree products for food security. Case study of a forest area in Northeast Thailand Uppsala: Swedish University of Agricultural Sciences and International Rural Development Centre; 1994

40. Kosaka Y, Takeda S, Prixar S, Sithirajvongsa S, Xaydala K: Species composition, distribution and management of trees in rice paddy fields in central Lao, PDR. Agroforestry Systems 2006, 67:1-17.

41. Kosaka Y, Takeda S, Sithirajvongsa S, Xaydala K: Plant diversity in paddy fields in relation to agricultural practices in Savannakhet Province, Laos. Economic Botany 2006, 60:49-61.

42. Foppes J, Ketphanh S: The use of non-timber forest products in Lao P.D. R. Proceedings of the"Workshop on Protected Area Management"; Xishuangbanna 1997.

43. Shibahara M: Hunting and gathering activities and public forests: the case of rainfed rice-cultivating villages in Roi Et, Northeastern Thailand. Southeast Asian Studies 2004, 42:354-377.

44. Khumkratok S, Wongpakam K, Kanchanamayoon W: Edible plants in cultural forest of Northeast Thailand. CBD Technical Series No 17 "Working together for biodiversity: regional and international initiatives contributing to achieving and measuring progress towards the 2010 target" Abstracts of poster presentations at the 10th Meeting of the Subsidiary Body on Scientific, Technical and Technological Advice of the Convention on Biological Diversity Montreal: Secretariat of the CBD; 2005.

45. Johnson N, Grivetti LE: Environmental change in Northern Thailand: impact on wild edible plant availability. Ecology of Food and Nutrition 2002, 41:373-399.

46. Chanaboon T, Tonboon W, Khumkratok S, Wongpakam K: Plant diversity in agricultural areas of some ethnic groups in Northeastern Thailand. CBD Technical Series No 17 "Working together for biodiversity: regional and international initiatives contributing to achieving and measuring progress towards the 2010 target" Abstracts of poster presentations at the 10th Meeting of the Subsidiary Body on Scientific, Technical and Technological Advice of the Convention on Biological Diversity Montreal: Secretariat of the CBD; 2005.

47. Schoenly K, Mew TW, Reichardt W: Biological diversity of rice landscapes. In Sustainability of rice in the global food system. Edited by: Dowling NG, Greenfield SM, Fischer KS. Manila: Pacific Basin Study Center - IRRI; 1998:

48. Vityakon P: The role of trees in countering land degradation in cultivated fields in Northeast Thailand. Southeast Asian Studies 2001, 39:398-416.

49. Miyagawa S: Overview of the project on the tree-rice ecosystem in paddy fields. Proceedings of the International Symposium "Tree-rice ecosystem in the paddy fields of Laos"; Vientiane, Laos 2008.

50. Watanabe H, Abe Kl, Hoshikawa T, Prachaiyo B, Sahunalu P, Khemnark C: On trees in paddy fields in Northeast Thailand. Southeast Asian Studies 1990, 28:45-54.

51. Vityakon P: The traditional trees-in-paddy-fields agroecosystem of Northeast Thailand: its potential for agroforestry development. Regional Development Dialogue 1993, 14:125-148.

52. Vityakon $P$, Dangthaisong $N$ : Environmental influences on nitrogen transformation of different quality tree litter under submerged and aerobic conditions. Agroforestry Systems 2005, 63:225-236.

53. Vityakon P: Degradation and restoration of sandy soils under different agricultural land uses in Northeast Thailand: a review. Land Degradation and Development 2007, 18:567-577.

54. Funahashi K, Adachi Y: Local knowledge of trees on paddy fields in Dong Khuai village. Proceedings of the International Symposium "Tree-rice ecosystem in the paddy fields of Laos"; Vientiane, Laos 2008.

55. Maneechote C: Utilization of weeds and their relatives as resources in Thailand. In Utility of weeds and their relatives as resources. Edited by: Kim KU, Shin DH, Lee IJ. Daegu, Korea: Kyungpook National University; 2007:

56. Vongsaroj P, Nuntasomsaran P: Weed utilization in Thailand. Proceedings II of the 17th Asian-Pacific Weed Science Society Conference "Weeds and environmental impact"; Bangkok 1999.

57. Vongsaroj P: Weeds and weed management alternatives for cash crops Bangkok: Ministry of Agriculture; 2005.

58. Kim KU, Shin DH, Lee IJ: Utility of weeds and their relatives as resources Daegu, Korea: Kyungpook National University; 2007.

59. Bangkok Forest Herbarium: Flora of Thailand Bangkok: Office of the Forest Herbarium, Department of National Parks, Wildlife and Plant Conservation.

60. Germplasm Resources Information Network - (GRIN) [Online Database]. [http://www.ars-grin.gov/cgi-bin/npgs/html/stdlit.pl?PI\%20Res\%20SEAs].

61. Multilingual Multiscript Plant Name Database. [http://www.plantnames. unimelb.edu.au/Sorting/List_bot.html].

62. E-PROSEA. [http://www.proseanet.org].

63. Smitinand T: Thai plant names Bangkok: The Forest Herbarium, Royal Forest Department; 2001

64. Morgan DL, Kreuger RA: When to use focus groups and why. In Successful focus groups. Edited by: Morgan DL. London: Sage; 1993:

65. Bernard HR: Research methods in anthropology. Qualitative and quantitative approaches Walnut Creek/London/New Delhi: Altamira Press; 2002

66. Pelto PJ, Pelto GH: Anthropological research: the structure of inquiry Cambridge, London and New York: Cambridge University Press; 1996.

67. Etkin NL, Ross PJ: Food as medicine and medicine as food. An adaptive framework for the interpretation of plant utilization among the Hausa of Northern Nigeria. Social Science and Medicine 1982, 16:1559-1573.

68. Pieroni A, Quave CL: Functional foods or food medicines? On the consumption of wild plants among Albanians and Southern Italians in Lucania. In Eating and healing, traditional food as medicine. Edited by: Pieroni A, Price L. New York: Food Products Press, an imprint of The Haworth Press, Inc.; 2005:101-129. 
69. Ali-Shtayeh M, Jamous R, Al-Shafie' J, Elgharabah W, Kherfan F, Qarariah K, Khdair I, Soos I, Musleh A, Isa B, et al: Traditional knowledge of wild edible plants used in Palestine (Northern West Bank): A comparative study. Journal of Ethnobiology and Ethnomedicine 2008, 4:13.

70. Wujisguleng W, Khasbagen $K$ : An integrated assessment of wild vegetable resources in Inner Mongolian Autonomous Region, China. Journal of Ethnobiology and Ethnomedicine 2010, 6:34.

doi:10.1186/1746-4269-7-33

Cite this article as: Cruz-Garcia and Price: Ethnobotanical investigation of 'wild' food plants used by rice farmers in Kalasin, Northeast Thailand. Journal of Ethnobiology and Ethnomedicine 2011 7:33.

Submit your next manuscript to BioMed Central and take full advantage of:

- Convenient online submission

- Thorough peer review

- No space constraints or color figure charges

- Immediate publication on acceptance

- Inclusion in PubMed, CAS, Scopus and Google Scholar

- Research which is freely available for redistribution

Submit your manuscript at www.biomedcentral.com/submit 